Margaret E. L. Renwick

The Phonetics and Phonology of Contrast 


\section{Phonology and Phonetics}

Edited by

Aditi Lahiri

Volume 19 


\section{Margaret E. L. Renwick}

The Phonetics

and Phonology

of Contrast

The Case of the Romanian Vowel System

\section{DE GRUYTER}

MOUTON 
ISBN 978-3-11-036215-2

e-ISBN (PDF) 978-3-11-036277-0

e-ISBN (EPUB) 978-3-11-039476-4

ISSN 1861-4191

\section{Library of Congress Cataloging-in-Publication Data}

A CIP catalog record for this book has been applied for at the Library of Congress.

Bibliographic information published by the Deutsche Nationalbibliothek

The Deutsche Nationalbibliothek lists this publication in the Deutsche Nationalbibliografie; detailed bibliographic data are available on the Internet at http://dnb.dnb.de.

(C) 2014 Walter de Gruyter GmbH, Berlin/Boston

Printing and binding: CPI books $\mathrm{GmbH}$, Leck

(2) Printed on acid-free paper

Printed in Germany

www.degruyter.com 
for John 
